Institute of $\mathbf{F}_{\text {ood and }} \mathbf{A}_{\text {gricultural }} \mathbf{S}_{\text {ciences }}$

\title{
Blister Beetles (Insecta: Coleoptera: Meloidae) ${ }^{1}$
}

\section{Richard B. Selander and Thomas R. Fasulo ${ }^{2}$ Introduction}

The family Meloidae, blister beetles, contains about 2500 species, divided among 80 genera and three subfamilies. Florida has 26 species, only a small fraction of the total number in the U.S., but nearly three times that in the West Indies (Selander and Bouseman 1960). Adult beetles are phytophagous, feeding especially on plants in the families Amaranthaceae, Compositae, Leguminosae, and Solanaceae. Most adults eat only floral parts, but some, particularly those of Epicauta spp., eat leaves as well. A few adults are nocturnal; most are diurnal or show no distinct diel cycle. Since adults are gregarious and often highly colored, they tend to be conspicuous. However, except for first instar larvae (triungulins) frequenting flowers or clinging to adult bees, larval blister beetles are seldom seen. So far as known, all larvae are specialized predators. Larvae of most genera enter the nests of wild bees, where they consume both immature bees and the provisions of one or more cells. Those of some Meloinae, including most Epicauta spp., prey on the eggs of acridid grasshoppers. A few larvae evidently prey on the eggs of blister beetles (Selander 1981). Of the Florida species, Nemognatha punctulata LeConte (misidentified as Zonitis vittigera (LeConte)) has been found in a nest of a Megachile sp. in Cuba (Scaramuzza 1938) and several members of the genus Epicauta have been associated with the eggpods of Melanoplus spp.

\section{Distribution}

Fourteen of the Florida species are limited largely or entirely to the Atlantic and/or Gulf coasts of the U.S. Ten species are more or less widely distributed in the central and/or eastern states. Two species occur both in the southeastern U.S. and the West Indies. No species is endemic. Both species ranging into the West Indies belong to South and Central American groups and probably reached the continental U.S. from the islands. A third, weaker faunal link with the West Indies is represented by Pseudozonitis longicornis (Horn), whose group includes one West Indian species and two relictual species in east Texas (Enns 1956, Selander and Bouseman 1960).

1. This document is EENY-166 (originally published as DPI Entomology Circular 268), one of the Featured Creatures series of the Entomology and Nematology Department, Cooperative Extension Service, Institute of Food and Agricultural Sciences, University of Florida. Published: October 2000. Revised: August 2003. This document is also available on Featured Creatures Website at http://creatures.ifas.ufl.edu. Please visit the EDIS Website at http://edis.ifas.ufl.edu. Additional information on these organisms, including many color photographs, is available at the Entomology and Nematology Department website at http://entnemdept.ifas.ufl.edu/.

2. Richard B. Selander, Department of Genetics and Development, University of Illinois at Urbana-Champaign, and Thomas R. Fasulo, Entomology and Nematology Department, Cooperative Extension Service, Institute of Food and Agricultural Sciences, University of Florida, Gainesville, FL.

The Institute of Food and Agricultural Sciences (IFAS) is an Equal Employment Opportunity - Affirmative Action Employer authorized to provide research, educational information and other services only to individuals and institutions that function without regard to race, creed, color, religion, age, disability, sex, sexual orientation, marital status, national origin, political opinions or affiliations. For information on obtaining other extension publications, contact your county Cooperative Extension Service office. Florida Cooperative Extension Service / Institute of Food and Agricultural Sciences / University of Florida / Larry R. Arrington, Interim Dean 


\section{Description}

Adults are rather soft-bodied, long-legged beetles with the head deflexed, fully exposed, and abruptly constricted behind to form an unusually narrow neck, the pronotum much narrower at the anterior end than the posterior and not carinate (keeled) laterally, the forecoxal cavities open behind, and (in all Florida species) each of the tarsal claws cleft into two blades. Body length generally ranges between $3 / 4$ and $2 \mathrm{~cm}$ in the Florida species. Families with which blister beetles are likely to be confused are Oedemeridae (Arnett 1984) and Lagriidae.

Triungulin larvae of Nemognathinae found in flowers or attached to the hairs of bees are sometimes mistaken for those of Rhipiphoridae. In both groups, the body is navicular and heavily sclerotized and there is a definite pattern of setation. Nemognathine larvae are distinctive in having one to two (not four to five) stemmata on each side of the head, an ecdysial line on the thorax, and no pulvilli (bladderlike appendages).

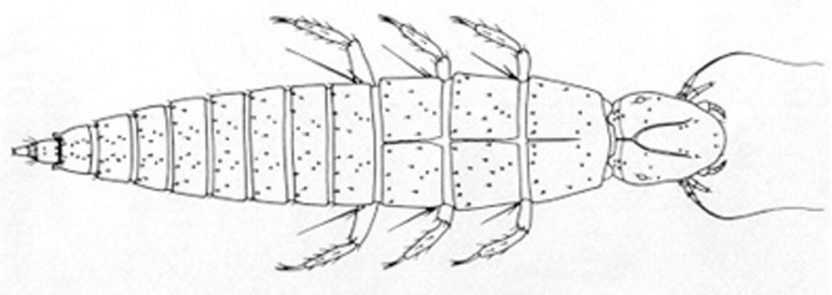

Figure 1. Nemognatha plazata Fabricius, triungulin. Credits: Division of Plant Industry

Keys to genera for adult beetles and triungulin larvae are given in references (Arnett 1960) and (MacSwain 1956), respectively. Adults of most of the Florida species are described by Enns and Werner (Enns 1956, Werner 1945).

\section{Life Cycle}

Eggs are laid in masses in the ground or under stones (Meloinae) or on the food plants of adults (Nemognathinae). Larval development is hypermetamorphic, with four distinct phases.

In the first instar or triungulin $(\mathrm{T})$ phase the larva reaches its feeding site on its own (most Meloinae) or is carried there by an adult bee, to

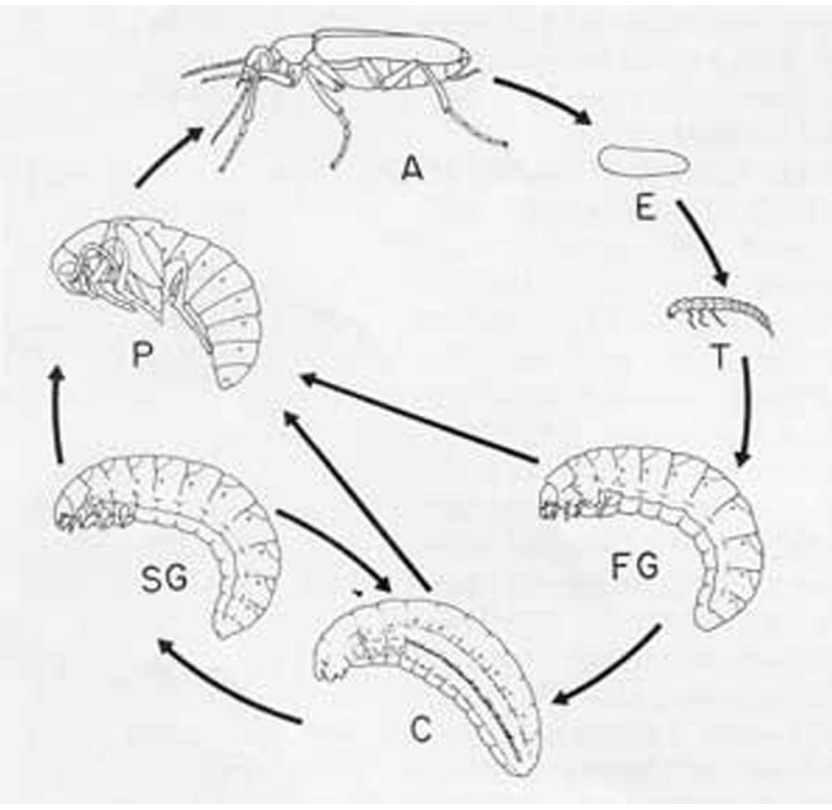

Figure 2. Blister Beetle Life Cycle $A=$ adult, $E=$ egg, $T=$ first instar or triungulin, $F G=$ first grub phase, $C=$ coarctate phase in instar six or seven, $S G=$ second grub phase, $\mathrm{P}=$ pupa Credits: Division of Plant Industry

which the larva attaches from a flower (Meloini (not in Florida) and Nemognathinae). After feeding to repletion, the larva, with ecdysis, becomes scarabaeiform and enters a period of rapid growth (first grub phase, FG) that lasts until the end of instar five or six. In some species that prey on bees the FG larva uses only a single cell; in others it digs into nearby cells and devours their contents. In Meloinae the fully fed FG larva generally excavates a chamber apart from the feeding site. In instar six or seven, the larva typically becomes heavily sclerotized and immobile (coarctate phase, C). In this phase the musculature undergoes profound degeneration and respiration is reduced to an extremely low level, permitting survival for more than a year, if necessary. When development resumes the muscles regenerate and, with ecdysis, the larva once again becomes scarabaeiform (second grub phase, $\mathrm{SG}$ ); at this point it may or may not excavate a pupal chamber. Nemognathinae are unusual in that the SG larva and following pupa and adult are encapsulated by the cast but intact skins of the last instar FG larva and the C larva.

Several alternative developmental pathways have been identified. In response to high temperature, many Epicauta larvae pupate directly from the FG phase or fail to diapause in the $\mathrm{C}$ phase; both patterns 
are conducive to multivoltinism. Rarely, a larva pupates directly from the $\mathrm{C}$ phase. Presumably in response to adverse environmental conditions, larvae of several genera of Meloinae can return to the $\mathrm{C}$ phase after reaching the SG phase. Most species pass the winter or dry season as coarctate larvae; a few do so as diapausing eggs, triungulin larvae, or adults.

Adults commonly live three months or more. Females typically mate and oviposit periodically throughout their adult lives.

\section{Medical and Veterinary Importance}

Blister beetles receive their common name from the ability of their hemolymph to produce blistering on contact with human skin. Hemolymph is often exuded copiously by reflexive bleeding when an adult beetle is pressed or rubbed. Blisters commonly occur on the neck and arms, as the result of exposure to adult beetles attracted to outdoor lights at night. General handling of adults seldom results in blistering unless the hemolymph contacts the relatively thin skin between the fingers. Unless extensive, medical treatment beyond first aid for blistering on humans is probably not necessary. The blistering on the individual shown in the photograph, while uncomfortable, was not painful. The blisters soon diminished on their own.

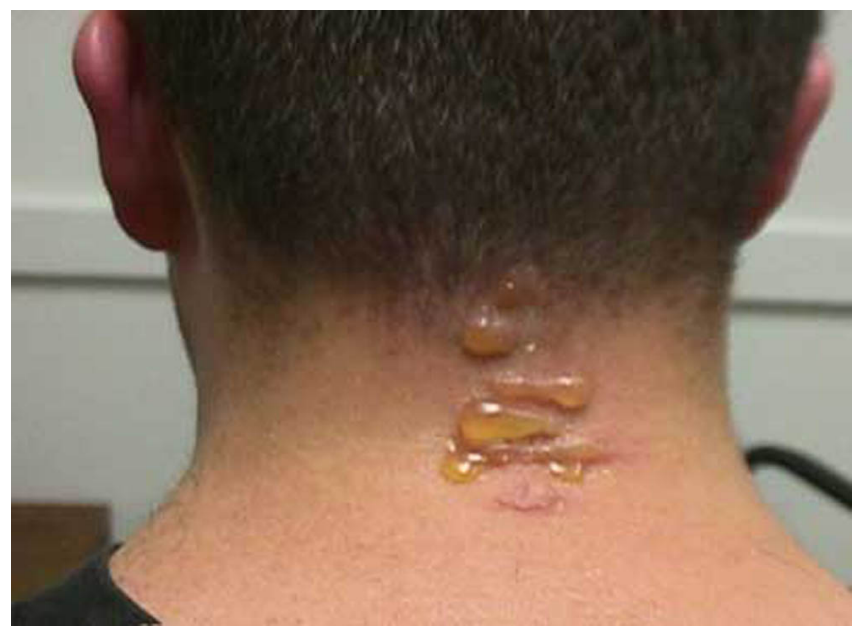

Figure 3. Blisters resulting by smashing a single blister beetle on the neck. While uncomfortable, no medical treatment was implemented and the blisters soon diminished on their own. Credits: Samuel Grubb, US Cellular
The blistering agent is cantharidin, an odorless terpene (exo-1,2-cis-dimethyl-3,6-epoxyhexahydro-phthalic anhydride) occurring elsewhere only in beetles of the family Oedemeridae (Arnett 1984). Cantharidin or cantharides (dried, pulverized bodies of adult beetles) was once employed extensively in human and veterinary medicine, primarily as a vesicant and irritant and is still used in the U.S. as the active ingredient in a proprietary wart remover. Taken internally or absorbed through the skin, cantharidin is highly toxic to mammals. There is an extensive literature dealing with its reputed aphrodisiacal properties and numerous reports of human poisonings, both accidental and deliberate. Cantharides is sometimes specified as the Eurasian Spanishfly, Lytta vesicatoria (Linnaeus); however, other genera, particularly Mylabris and Epicauta, have been more commonly used, especially for extraction of cantharidin. Recorded cantharidin content of adult beetles (by dry weight) ranges from less than $1 \%$ to a high of $5.4 \%$. Biological synthesis and function have been largely neglected. It is widely assumed that cantharidin confers chemical protection from predators, but there is little evidence for this. In at least some species, females receive large quantities of cantharidin from males during copulation. In any case, females incorporate the material in a coating applied to the eggs.

Cases of fatal poisonings of valuable horses in Florida, Oklahoma, Tennessee, and Texas by ingestion of blister beetles trapped in baled alfalfa hay (Mackay and Wollenman 1981, Schoeb and Panciera 1979) have revived interest in the pathology of cantharidin toxicosis and led to the development of a highly sensitive technique for detection of the compound (Ray et al. 1979). Poisonings have been traced to adults of Epicauta occidentalis Werner and, possibly, E. temexa Adams \& Sel. Neither species occurs in Florida, but a close relative (the striped blister beetle, E. vittata (Fabricius)) and three other species of the genus (the clematis blister beetle, $E$. fabricii (LeConte); the black blister beetle, $E$. pennsylvanica (De Geer); and the margined blister beetle, E. pestifera Werner) occur in alfalfa fields here and pose a potential threat if horse owners turn to locally grown alfalfa as a source of hay. Research is available to indicate the amount of cantharidin levels 
present in common species, as well as the estimated number of beetles necessary to provide a lethal dose to horses (Sansome 2002).

\section{Crop Damage}

Several of the Florida blister beetles feed on cultivated plants. Species of Epicauta, particularly the margined blister beetle, E. pestifera, and the striped blister beetle, E. vittata, often damage alfalfa, beet, potato, tomato, and other crops by defoliation. Because of the beetles' gregarious behavior, their attacks can be locally catastrophic. In small gardens, it may be sufficient simply to pick the beetles from the plants.

Insect Management Guide: Vegetables

Insect Management Guide: Field Crops and Pastures

\section{Annotated List of Species}

In the following list, geographic distribution outside Florida is not summarized for species that range considerably beyond the Gulf and Atlantic coasts in the U.S. Seasonal distribution is not mentioned for species that are active in the adult stage from spring to late summer or early fall. In general, summaries of food plants do not pertain exclusively to Florida.

\section{Meloinae}

Pyrota limbalis LeConte. Washington, D.C., south to Highlands County, Florida. One record at light.

P. lineata (Olivier). Northern Florida, including the panhandle, south to Polk County.

August-October. Several Compositae and Gerardia (Scrophulariaceae).

P. mutata (Gemm.). Northern Florida, including the panhandle, south to Polk County. Cicuta, Daucus, Eryngium, and several other Umbelliferae.

P. sinuata (Olivier). Coastal Plain from Mississippi to North Carolina; south in Florida to Highlands County. Gerardia (Scrophulariaceae).

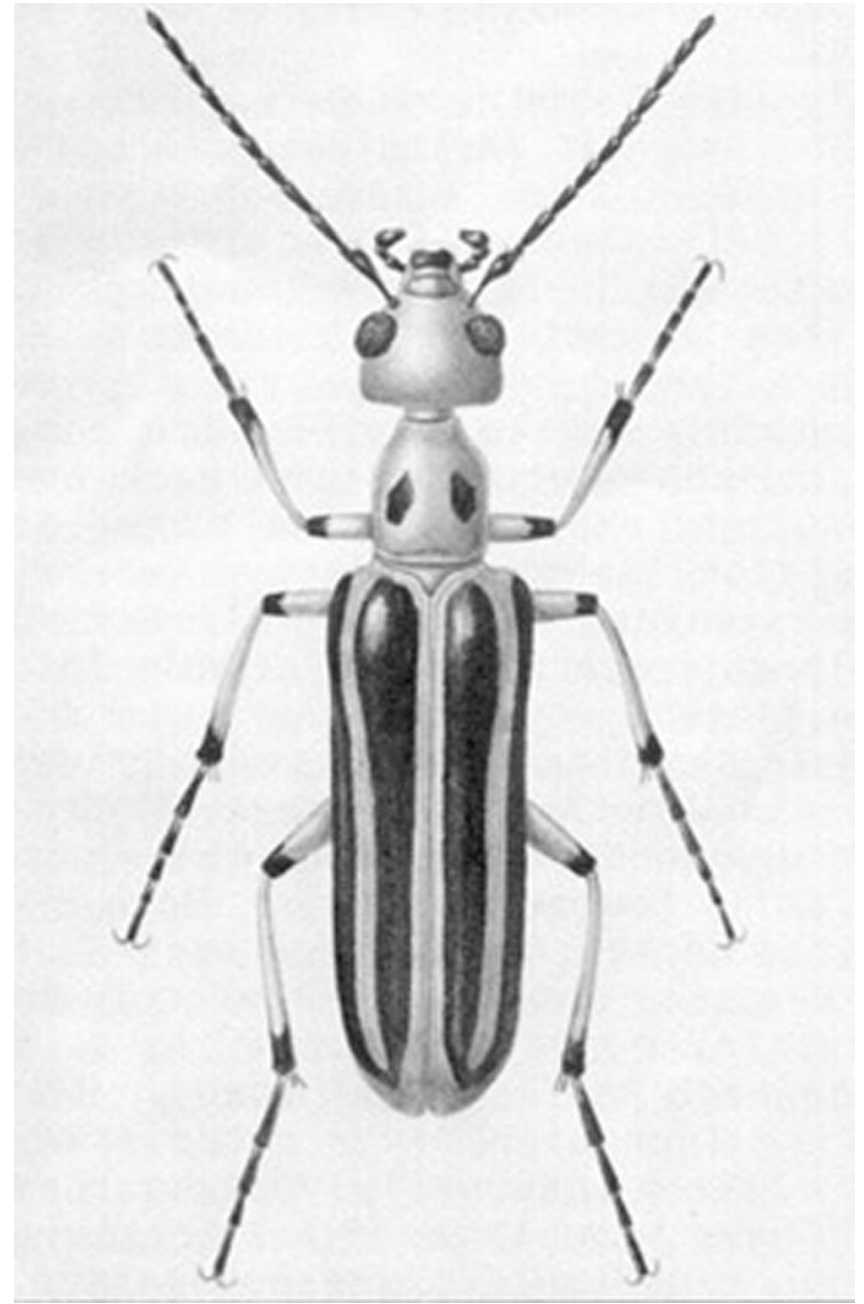

Figure 4. Adult Pyrota lineata (Olivier) a blister beetle. Credits: Division of Plant Industry

Lytta polita Say. Georgia border south to Charlotte and Highlands counties. December-June. Has been taken in large numbers at lights.

Epicauta batesi Horn. Coastal Plain from New Jersey to Alabama; south in Florida to Polk County

E. excavatifrons Maydell. Coastal Mississippi and Alabama and south in Florida to Marion County. September-October. Recorded twice from grass.

E. fabricii (LeConte) - the ashgray blister beetle. Northern Florida, including the panhandle, south to Highlands County. April-May. Commonly on Leguminosae, including alfalfa, Baptisia, bean, pea, and sweetclover; sometimes attacks potato and glandless cotton. At lights.

E. floridensis Werner. Primarily coastal, from Texas and Oklahoma to New Jersey; probably 


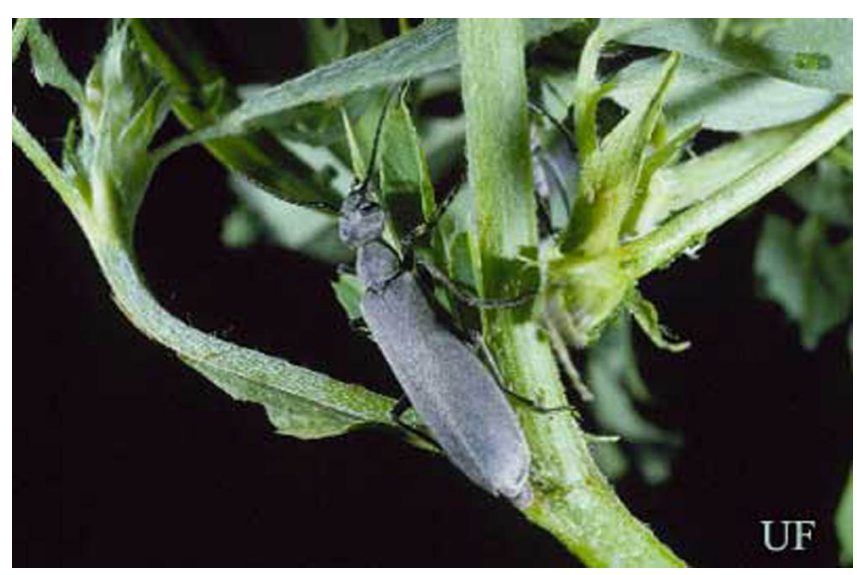

Figure 5. Adult Epicauta fabricii (LeConte), the ashgray blister beetle. Credits: John L. Capinera, University of Florida

statewide in Florida. Ipomoea (Convolvulaceae), Schrankia (Leguminosae), and (in captivity) Solanum (Solanaceae).

\section{E. heterodera Horn. Coastal Mississippi to} Georgia and south in Florida to Osceola County. September-November. Helenium and other Compositae.

E. pennsylvanica (De Geer) - the black blister beetle. Alachua, Leon, and Marion counties. Wide variety of plants, including many Compositae, Chenopodium (Chenopodiaceae), and such crops as alfalfa, beet, and potato.

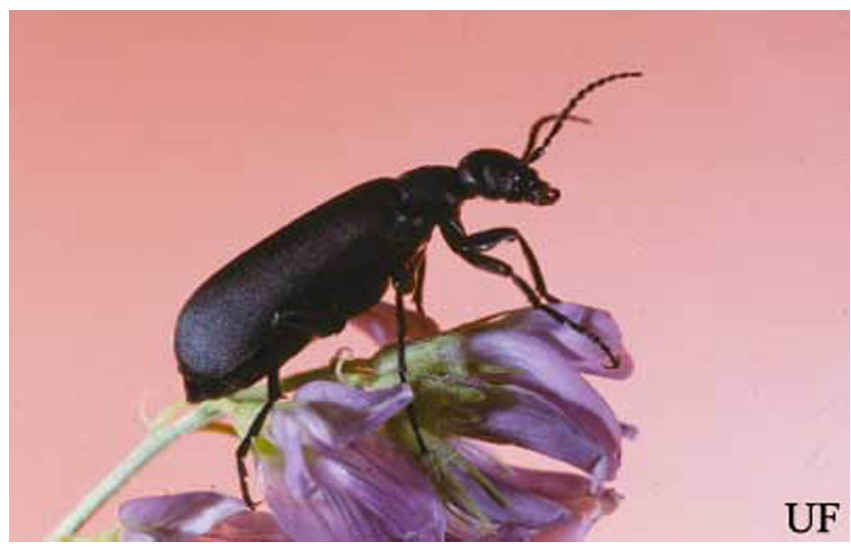

Figure 6. Adult Epicauta pennsylvanica (De Geer), the black blister beetle. Credits: John L. Capinera, University of Florida

E. pestifera Werner - the margined blister beetle. Northern Florida, including the panhandle, south to Indian River County Many Leguminosae and Solanaceae, including alfalfa, beet, egg plant, potato, soybean, and tomato.
E. sanguinicollis Horn. Alachua, Citrus, Sumter, and Brevard counties. Recorded in the literature only from Florida, but I have two specimens labeled "Savannah, Georgia." July and October. Compositae, Schrankia (Leguminosae), and cotton.

\section{E. strigosa (Gyll.). Coastal Plain from} Mississippi to New Jersey; probably statewide in Florida. Principally on Compositae, Opuntia (Cactaceae), Ipomoea (Convolvulaceae), and Vigna (Leguminosae). Common.

E. tenuis (LeConte). Described from an unspecified locality in Georgia and subsequently recorded in Florida from Baker and Volusia counties south to Highlands County. May-June.

E. torsa (LeConte). Oklahoma and east Texas, east on the Coastal Plain to Georgia and north to Massachusetts; probably statewide in Florida. April-June. Ilex (Aquifoliaceae), Sapindus (Sapindaceae), and Albizzia, Amorpha, and Robinia (Leguminosae).

E. vittata (Fabricius)- the striped blister beetle. Represented in Florida, where it occurs commonly throughout the state except for the Keys, by the "lemniscate" or southeastern coastal race (Adams and Selander 1979). March-May. Wide variety of plants, including Amaranthus (Amaranthaceae) and such crops as alfalfa, bean, beet, cotton, potato, and tomato. Attracted to lights.

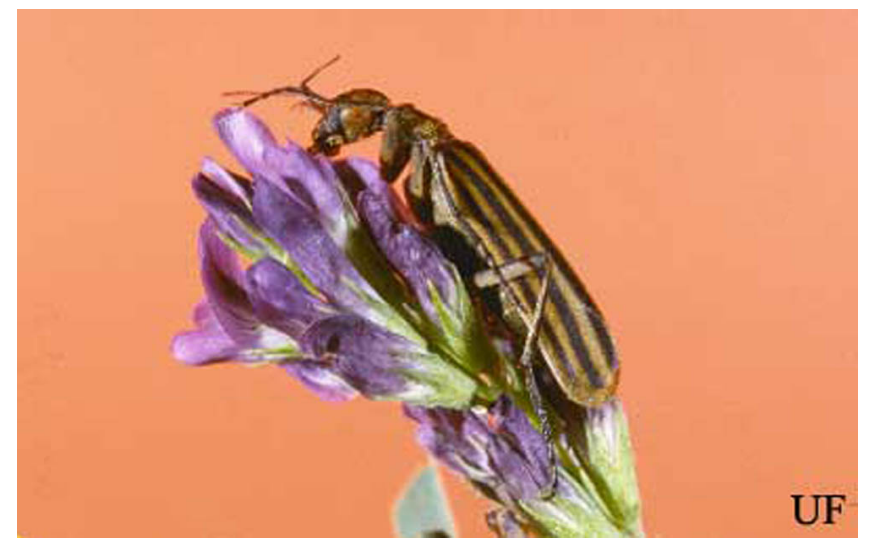

Figure 7. Adult Epicauta vittata (Fabricius), the striped blister beetle. Credits: John L. Capinera, University of Florida 


\section{Nemognathinae}

Tetraonyx quadrimaculata (Fabricius). Trinidad, Lesser Antilles, Puerto Rico, Hispañola, and the U.S. Coastal Plain from northern Florida (Alachua and Putnam counties) to Alabama and North Carolina. Convolvulaceae (Ipomoea) and Leguminosae (Bradburya, Coelosia) in the U.S. and these families and Bignoniaceae, Euphorbiaceae, and Verbenaceae in the West Indies. Reported damaging grapefruit flowers in Puerto Rico.

Nemognatha nemorensis Hentz. North Florida, south to Pinellas and Brevard counties. Several Compositae, including Bidens, Erigeron, Heterotheca, and, particularly, Rudbeckia.

N. piazata Fabricius. Represented in Florida by the nominate race (Mississippi to West Virginia south), which occurs statewide, including the Keys. Cirsium and Tetraognotheca (Compositae).

N. punctulata LeConte. Bahama and Cayman islands, Cuba, Jamaica, and the southeastern U.S. Recorded in Florida only from the Keys and Dade County. Bidens and "thistle" (Compositae). Not common.

Zonitis cribricollis (LeConte). Widely distributed in Florida, south to Dade County Achillea, Coreopsis, Helianthus, and Rudbeckia (Compositae). Rare.

Z. vittigera (LeConte). Represented in Florida, where it occurs south to Highlands County, by the nominate, eastern race. Numerous Compositae and Psoralea (Leguminosae).

Pseudozonitis longicornis (Horn). Kansas and east Texas east along the Coastal Plain to South Carolina; recorded in Florida from Highlands County south to the Keys. March-Jul. At lights. Rare.

P. pallida Dillon. Oklahoma and east Texas east to Florida, where it extends south through Dixie and Alachua counties to Hillsborough County. At lights. Not common.

P. schaefferi (Blatch.). A taxonomically isolated species known only from Florida (Pinellas, St. Johns, and Volusia counties) and Myrtle Beach, South Carolina (Kirk 1969). February-May.

\section{Selected References}

Adams CL, Selander RB. 1979. The biology of blister beetles of the Vittata Group of the genus Epicauta (Coleoptera, Meloidae). Bulletin of the American Musuem of Natural History 162: 139-266.

Arnett Jr RH. 1960. The Beetles of the United States. Catholic Univ. Press, Washington, D.C., xi + $1112 \mathrm{p}$.

Arnett JR RH. (September 2000). False blister beetles, Coleoptera: Oedemeridae. UF/IFAS Featured Creatures. EENY-154. http://creatures.ifas.ufl.edu/urban/medical/ false_blister_beetles.htm (19 October 2001).

Enns WR. 1956. A revision of the genera Nemognatha, Zonitis, and Pseudozonitis (Coleoptera, Meloidae) in America north of Mexico, with a proposed new genus. University of Kansas Scientific Bulletin 37: 685-909.

Kirk VM. 1969. A list of the beetles of South Carolina. Part I - Northern Coastal Plain. South Carolina Agricultural Experiment Station Technical Bulletin 1033: 1-124.

MacKay RJ, Wollenman P. 1981. An outbreak of blister beetle poisoning in horses in Florida. Florida Vet. Journal 10: 11-13.

MacSwain JW. 1956. A classification of the first instar larvae of the Meloidae (Coleoptera). University of California Publication Entomology 12: i-iv, 1-182.

Ray AC, Tamulinas SH, Reagor JC. 1979. High pressure liquid chromatographic determination of cantharidin, using a derivatization method in specimens from animals acutely poisoned by ingestion of blister beetles, Epicauta lemniscata. American Journal Vet. Research 40: 498-504.

Sansome D. (29 May 2002). Blister beetles. Insect F@ stSheets: Agriculture Series. http://dallas.tamu.edu/insects/old_site/Ent-2006.html (10 August 2003).

Scaramuzza LC. 1938. Breve nota acerca de dos parásitos de "Megachile sp." (Hymenoptera, 
Apoidea, Megachilidae). Mem. Soc. Cubana Hist. Nat. 12: 87-88.

Schoeb TR, Panciera RJ. 1979. Pathology of blister beetle (Epicauta) poisoning in horses. Vet. Pathol. 16: 18-31.

Selander RB. 1981. Evidence for a third type of larval prey in blister beetles (Coleoptera: Meloidae). Journal of the Kansas Entomological Society 54: 757-783.

Selander RB, Bouseman JK. 1960. Meloid beetles (Coleoptera) of the West Indies. Proceedings of the U.S. National Musuem 111: 197-226.

Werner FG. 1945. A revision of the genus Epicauta in America north of Mexico (Coleoptera, Meloidae). Bulletin of the Museum of Comparative Zoology (Harvard University) 95: 421-517. 